GAY DIRECTORS, GAY FILMS? 



\section{EMANUEL LEVY}

\section{GAY DIRECTORS GAY FILMS?}

Pedro Almodóvar, Terence Davies, Todd Haynes, Gus Van Sant, John Waters

COLUMBIA UNIVERSITY PRESS

NEW YORK 


$$
\begin{gathered}
\text { Columbia University Press } \\
\text { Publishers Since 1893 } \\
\text { New York Chichester, West Sussex } \\
\text { cup.columbia.edu } \\
\text { Copyright @ } 2015 \text { Columbia University Press } \\
\text { All rights reserved }
\end{gathered}
$$

Library of Congress Cataloging-in-Publication Data

Levy, Emanuel, 1947-

Gay directors, gay films? : Pedro Almodóvar, Terence Davies, Todd

Haynes, Gus Van Sant, John Waters / Emanuel Levy.

pages $\mathrm{cm}$

Includes bibliographical references and index.

ISBN 978-0-231-15276-1 (cloth : alk. paper) -

ISBN 978-0-231-15277-8 (pbk. : alk. paper) -

ISBN 978-o-231-52653-1 (ebook)

1. Homosexuality in motion pictures. 2. Gay motion picture producers and directors-United States. 3. Gay motion picture producers and directors-Europe. I. Title.

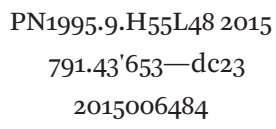

Columbia University Press books are printed on permanent and durable acid-free paper.

This book is printed on paper with recycled content.

Printed in the United States of America

c 10987654321

Cover Design: Jordan Wannemacher

References to websites (URLs) were accurate at the time of writing. Neither the author nor Columbia University Press is responsible for URLS that may have expired or changed since the manuscript was prepared. 
In Memory of Rob Remley

Love of My Life 
